\title{
Analisis Faktor-Faktor Yang Mempengaruhi Keputusan Pembelian
}

\author{
Dian Mardiana ${ }^{1}$, Rosdiana Sijabat $^{2}$ \\ ${ }^{1}$ Universitas Pelita Harapan \\ The Plaza Semanggi, Jl. Jend. Sudirman No.50, Jakarta, Indonesia \\ ${ }^{2}$ Universitas Katolik Indonesia Atma Jaya \\ Jl. Jenderal Sudirman No. 51, Jakarta, Indonesia \\ e-mail: ${ }^{1}$ kireyne_chan@yahoo.com, ${ }^{2}$ rosdiana.sijabat@atmajaya.ac.id
}

\begin{tabular}{llll}
\hline Informasi Artikel & Diterima: 02-08-2021 & Direvisi: 09-09-2021 & Disetujui: 23-01-2022 \\
\hline
\end{tabular}

\begin{abstract}
Abstrak
Tujuan penelitian ini adalah untuk menguji pengaruh positif dan signifikan consumer review online, promosi dan kepercayaan terhadap keputusan pembelian pada pembelian tiket pesawat di PT. XYZ selama pandemic Covid19. Data primer dikumpulkan dengan menggunakan kuesioner yang disebar melalui Google Form. Penelitian ini menggunakan sebanyak 400 responden pada anggota fan page PT. XYZ dengan teknik purposive sampling. Analisis data menggunakan analisis regresi linear berganda menggunakan program SPSS 25. Hasil penelitian menunjukkan bahwa consumer review online berpengaruh positif dan signifikan terhadap keputusan pembelian, Promosi berpengaruh positif dan signifikan terhadap keputusan pembelian dan kepercayaan berpengaruh positif dan signifikan terhadap keputusan pembelian.
\end{abstract}

Kata Kunci: Consumer Review Online, Promosi, Kepercayaan

\begin{abstract}
The purpose of this study is to examine the effect of consumer review online, promotions and trust in purchasing decisions on purchasing airplane tickets at XYZ, Inc. during the Covid-19 pandemic. Primary data were collected by using a questionnaire distributed via Google Form. The sampling method used was purposive sampling. Data analysis used multiple linear regression analysis with SPSS 25 program. The findings revealed that online consumer reviews positively and significantly influence purchasing decisions, promotion positively and significantly influence purchasing decisions and trust positively and significantly influence purchasing decisions.
\end{abstract}

Keywords: Consumer review online, Promotion, Trust

\section{Pendahuluan}

Industri transportasi udara atau penerbangan di Indonesia pada awal tahun 2020 mengalami gejolak penurunan kinerja yang cukup signifikan akibat kemunculan pandemi Covid-19 di berbagai belahan dunia termasuk di Indonesia. Penurunan kinerja ini tercermin dari anjloknya tingkat penjualan tiket pesawat selama pandemic Covid-19 berlangsung.

Ada banyak faktor yang menjadi pertimbangan konsumen dalam memilih brand maskapai yang akan digunakan, salah satunya adalah harga. Meskipun banyak maskapai yang menawarkan harga yang jauh lebih murah dengan kualitas yang cukup baik dan terjaga, namun PT. XYZtetap mendapat tempat di hati konsumen setianya serta menjadi pilihan bagi konsumen lainnya. Hal ini karena konsumen menaruh suatu kepercayaan bahwa PT. XYZakan memberikan pelayanan yang melebihi apa yang diharapkan oleh konsumen. Pengaruh positif dan signifikan kepecayaan terhadap keputusan pembelian telah dibuktikan oleh (Wakhidah, 2018), (Penia \& putu nina Madiawati, 2016) dan (Yuniarti, 2016). Namun penelitian (Ayuningtiyas \& Gunawan, 2018) menunjukkan hasil yang berbeda, yaitu berhubungan positif namun tidak berpengaruh signifikan.

Selain harga dan kepercayaan, dengan adanya perkembangan E-Commerce dan didukung dengan kemunculan fenomena penggunaan smartphone dalam keseharian, consumer review online juga memberikan pengaruh bagi konsumen dalam menentukan keputusan pembelian tiket pesawat terbang secara online. Ketika calon pembeli melihat dan membaca review online dari konsumen yang pernah menikmati jasa yang ditawarkan olehPT. XYZ, calon pembeli menjadi mantap dalam 
memutuskan pembelian tiket pesawat di PT. XYZ. Hal ini juga didukung oleh penelitian terdahulu yang telah membuktikan adanya pengaruh positif dan signifikan antara consumer review online terhadap keputusan pembelian seperti (Latief \& Ayustira, 2020) dan (Laili Hidayati, 2018). Tetapi hasil yang berbeda ditunjukkan oleh penelitian seperti (Mo et al., 2015) yang menemukan bahwa consumer review online tidak berpengaruh positif dan signifikan terhadap keputusan pembelian.

Promosi sebagai suatu cara untuk memperkenalkan produk ataupun untuk lebih menunjukkan keeksisan suatu produk, baik itu promosi harga maupun non harga juga sangat mendukung keputusan pembelian yang dilakukan oleh konsumen. Ketika seorang konsumen dihadapkan pada pilihan keputusan pembelian untuk suatu produk dengan harga dan kualitas yang sama, tentunya keberadaan produk yang memberikan adanya suatu promosi akan lebih dipilih oleh konsumen. Pengaruh positif dan signifikan promosi terhadap keputusan pembelian telah dibuktikan oleh peneliti terdahulu antara lain: (Erlangga et al., 2020) dan (Batu et al., 2020). Namun, penemuan (Aji, N. S., Djawahir, A. H., \& Rofiq, 2019) tidak sejalan dengan penelitian tersebut.

Dengan demikian penelitian ini bertujuan untuk mengetahui, menguji dan menganalisis apakah consumer review online, promosi dan kepercayaan berpengaruh positif dan signifikan terhadap keputusan pembelian pada pembelian tiket pesawat di PT. XYZselamapandemi Covid-19.

Menurut (Tjiptono, 2018) keputusan pembelian adalah suatu proses pengenalan masalah oleh konsumen yang dilanjutkan dengan pencarian informasi mengenai produk atau merk tertentu yang dianggap dapat menyelesaikan masalahnya dan mengevaluasinya terlebih dahulu yang kemudian mengarah pada keputusan pembelian. Menurut (Kotler \& Keller, 2020), terdapat empat indikator keputusan pembelian, yaitu: kemantapan pada sebuah produk, kebiasaan dalam membeli produk, memberikan rekomendasi pada orang lain, melakukan pembelian ulang.

Consumer review online merupakan konten yang berasal dari pihak pelanggan yang pernah membeli atau menikmati suatu produk atau jasa, dengan memberikan suatu penilaian atas produk atau jasa tersebut, baik berupa kata-kata atau numerik, yang biasanya mewakili seberapa besar kepuasan pelanggan tersebut. Menurut Park dan Kim dalam (Fong et al., 2018), consumer review online merupakan suatu kumpulan opini tentang suatu produk dari perspektif pelanggan yang diyakini tidak memilik bias atau pola terstruktur bagi konsumen untuk memposting pengalaman dalam membeli produk secara online. (Mo et al., 2015) dalam jurnalnya mengatakan bahwa review yang ada pada website e- commerce yang berbeda juga memiliki sistem yang berbeda namun sama-sama terkait dengan logistic rating, services rating, description rating dan comment review. (Lupiyoadi, 2015) menyebutkan ada tiga indikator costumer review online yaitu: 1) Konsumen mendapatkan informasi tentang produk, 2) Konsumen terdorong untuk melakukan pembelian disebabkan oleh adaya motivasi yang diperoleh dari orang lain, 3) Konsumen mendapatkan rekomendasi dari orang lain. Sementara (Mo et al., 2015) menyebutkan 3 (tiga) faktor utama review, yaitu: kuantitas, kualitas dan konsistensi. (Chang, 2017) juga menyebut 3 kategori dalam mengevaluasi review, yaitu: peringkat, volume peringkat, review.

\section{Metode Penelitian}

Populasi dalam penelitian ini adalah pembeli tiket PT. XYZsecara online. Sampel yang digunakan dalam penelitian ini adalah semua populasi yang tergabung dalam fan page PT. XYZ, yang berjumlah 2.098.238. Jumlah sampel ditentukan sebanyak 400 yang dihasilkan dengan menggunakan rumus slovin, Metode penarikan sampling yang digunakan adalah nonprobability sampling, yaitu dengan teknik purposive sampling. Metode analisis data yang digunakan adalah analisis deskriptif, dan analisis inferensial dengan menggunakan teknik analisis regresi berganda dengan formula sebagai berikut:

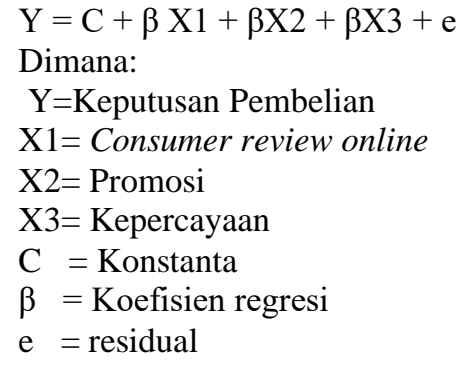

Pada penelitian ini dimensi untuk variabel Consumer review online yang digunakan didasarkan pada penelitian (Lupiyoadi, 2015), yaitu: konsumen mendapatkan informasi tentang produk, konsumen terdorong untuk melakukan pembelian disebabkan oleh adanya motivasi yang diperoleh dari orang lain, konsumen mendapatkan rekomendasi dari orang lain dan

Penelitian (Xie et al., 2015), yaitu kuantitas dan kualitas. Dimensi untuk variabel promosi didasarkan pada penelitian (Park et al., 2018), yaitu: Promosi harga dan promosi non-harga. Dimensi untuk variabel kepercayaan didasarkan pada penelitian Oliveira, yaitu: kompetensi, integritas dan benevolence (kebaikan) (Oliveira et al., 2017). Sedangkan untuk dimensi untuk variabel keputusan pembelian didasarkan pada (Kotler \& Keller, 2020), yaitu kemantapan pada sebuah produk, kebiasaan dalam membeli produk, memberikan rekomendasi pada orang lain, melakukan pembelian ulang. 


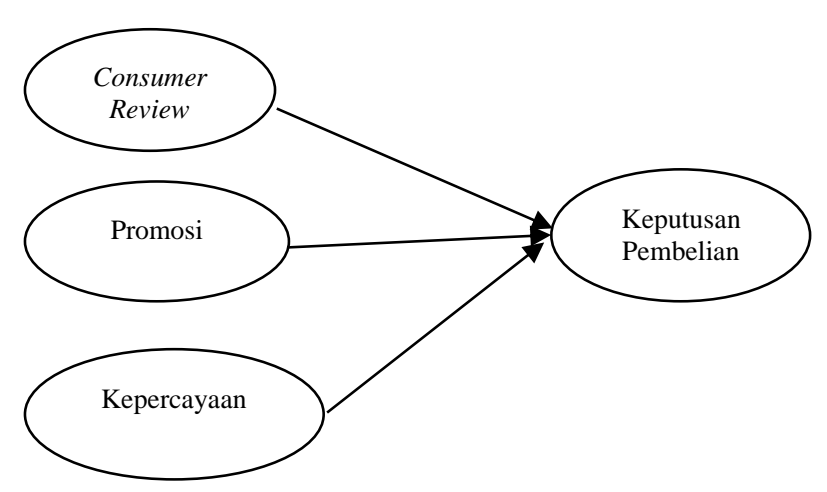

Gambar 1. Model Penelitian

\section{Hasil dan Pembahasan \\ Analisis Deskriptif}

Analisis deskriptif dilakukan dengan menentukan jumlah skor untuk masing-masing item pertanyaan, yang dilakukan dengan mengalikan skala dengan frekuensi untuk masing-masing item pertanyaan. Mengikuti pendekatan tersebut diperoleh hasil, bahwa untuk consumer review online, untuk semua pertanyaan dari variabel consumer review online, kecuali pertanyaan keenam dapat dikategorikan sebagai tingkat sangat tinggi. Sementara pertanyaan keenam, dapat dikategorikan sebagai tingkat tinggi. Sehingga secara keseluruhan untuk variabel consumer review online dapat dikategorikan dalam kelompok sangat tinggi. Adapun untuk variabel promosi untuk kesemua enam pertanyaan pada variabel promosi dapat dikategorikan sebagai tingkat cukup. Sementara untuk variabel kepercayaan, untuk kesemua tujuh pertanyaan pada variabel kepercayaan dapat dikategorikan sebagai tingkat sangat tinggi.

\section{Analisis Regresi Berganda}

Analisis ini digunakan untuk mengetahui pengaruh positif dan signifikan consumer review online, promosi dan kepercayaan terhadap keputusan pembelian. Hasil penelitian dengan menggunakan program SPSS 25, disajikan dalam tabel berikut:

Tabel 1. Hasil Uji Hipotesis

\begin{tabular}{lccc}
\hline \multicolumn{1}{c}{ Model } & \multicolumn{2}{c}{$\begin{array}{c}\text { Unstandardized } \\
\text { Coefficents }\end{array}$} & \\
\cline { 2 - 3 } & $\mathrm{B}$ & $\begin{array}{c}\text { Std. } \\
\text { Error }\end{array}$ \\
\hline $\begin{array}{l}\text { Consumer } \\
\text { review }\end{array}$ & 0,119 & 0,029 & 4,060 \\
$\begin{array}{l}\text { online } \\
\text { Promosi }\end{array}$ & 0,085 & 0,027 & 3,086 \\
$\begin{array}{l}\text { Kepercaya } \\
\text { an }\end{array}$ & 0,412 & 0,030 & 13,700 \\
\hline
\end{tabular}

Berdasarkan Tabel 1, dapat disimpulkan bahwa nilai $\mathrm{T}$ statistik untuk masing-masinghipotesis, lebih besar dari T tabel (T critical value), sehingga $\mathrm{H} 0$ untuk masing-masinghipotesis berhasil untuk ditolak, atau $\mathrm{Ha}$ untuk masing-masing hipotesis diterima, sehingga dapat disimpulkan terdapat pengaruh signifikan antara consumer review online, promosi dan kepercayaan terhadap keputusan pembelian. Nilai koefisien regresi untuk masing-masing variabel independen bernilai positif, yaitu consumer review online sebesar 0,119 , promosi sebesar 0,085 , dan kepercayaan sebesar 0,412, sehingga dapat disimpulkan bahwa masing-masing variabel independen mempunyai hubungan positif terhadap variabel keputusan pembelian.

\section{Uji F}

Uji $\mathrm{F}$ dilakukan untuk mengetahui pengaruh variabel consumer review online, promosi dan kepercayaan secara bersama-sama terhadap variabel keputusan pembelian. Hasil uji F statistik dengan program SPSS ditampilkan dalam Tabel 2 berikut:

\begin{tabular}{llll}
\multicolumn{3}{c}{ Tabel 2 Hasil Uji F } \\
\hline Model & Df & $\begin{array}{l}\boldsymbol{F} \\
\text { Statistic }\end{array}$ & Sig \\
& & 108,003 & 0,000 \\
Regresi & 3 & & \\
Residual & 396 & & \\
Total & 399 & &
\end{tabular}

Sumber: data primer diolah.

Berdasarkan Tabel 2 terlihat bahwa signifikansi uji $\mathrm{F}$ adalah 0,000 yang nilainya lebih kecil dari 0,05 atau F Statistik sebesar 108,003 lebih besar dari F Tabel sebesar 2,627, sehingga H0 ditolak dan Ha diterima. Sehingga dapat dsimpulkan bahwa terdapat pengaruh langsung antara variabel consumer review online, promosi dan kepercayaan secara bersama-sama terhadap variabel keputusan pembelian.

\section{Analisis Koefisien Determinasi $\left(\mathbf{R}^{\mathbf{2}}\right)$}

Koefisien determinasi digunakan untuk menentukan seberapa besar variabel consumer review online, promosi dan kepercayaan secara bersamasama dalam menjelaskan variabel keputusan pembelian. Hasil analisis koefisien determinasi dengan menggunakan program SPSS 25, ditampilkan dalam tabel berikut:

Tabel 3. Hasil Analisis Koefisien Determinasi

\begin{tabular}{ll}
\hline $\begin{array}{l}\text { Adjusted R } \\
\text { Square }\end{array}$ & $\begin{array}{l}\text { Std. Error of the } \\
\text { Estimate }\end{array}$ \\
\hline 0,446 & 2,2024 \\
\hline
\end{tabular}

Sumber: Data primer diolah.

Berdasarkan Tabel 3, nilai adjusted $R$ square sebesar 0,446 atau 44,6\%. Hal ini menunjukkan bahwa variabel consumer review online, promosi dan kepercayaan secarabersama-sama mempunyai 
kontribusi sebesar 44,6\% dalam menjelaskan variabel keputusan pembelian. Sementara sisanya sebesar $55,4 \%$ dijelaskan oleh variabel lain yang tidak disebutkan dalam penelitian ini.

\section{Pembahasan}

Pada pengujian hipotesis 1 , berhasil membuktikan bahwa terdapat pengaruh positif dan signifikan antara variabel consumer review online terhadap variabel keputusan pembelian. Hasil ini sejalan dan memperkuat penelitian terdahulu yaitu seperti (Latief \& Ayustira, 2020) dan (Laili Hidayati, 2018) yang menunjukkan bahwa terdapat hubungan positif antara varabel consumer review online terhadap variabel keputusan pembelian. Berdasarkan hasil penelitian ini, maka dapat diinteprestasikan bahwa meskipun ditengah pandemi Covid-19, keberadaan consumer review online tetap sangat berpengaruh terhadap keputusan pembelian. Hal ini dapat dilihat dari tingkat kontribusi consumer review online dalam menjelaskan keputusan pembelian, yaitu sebesar $18,90 \%$. Nilai ini tidaklah terlalu besar dan kuat, bisa jadi karena consumer review online bukanlah faktor utama yang menyebabkan seseorang memutuskan untuk membeli tiket online di PT. XYZPenelitian ini juga berhasil membuktikan bahwa terdapat pengaruh positif dan signifikan antara variabel promosi dan keputusan pembelian. Hal ini senada dengan penelitian terdahulu seperti (Erlangga et al., 2020) dan (Batu et al., 2020). Namun penelitian ini tidak sejalan penelitian (Aji, N. S., Djawahir, A. H., \& Rofiq, 2019) yang menemukan bahwa variabel promosi tidak berrpengaruh signifikan terhadap variabel keputusan pembelian. Namun meskipun berhasil membuktikan bahwa terdapat pengaruh positif dan signifikan antara variabel promosi dan variabel keputusan pembelian, taraf menjelaskan variabel promosi terhadap variabel keputusan sangat rendah, yaitu 0,000. Hal ini dimungkinkan karena rendahnya tingkat promosi yang dilakukan oleh PT. XYZ. Hal ini juga bisa dimaklumi, karena ketika kondisi pandemi Covid-19 sedang mewabah, meskipun pihak PT. XYZmelakukan promosi besarbesaran, maka usaha promosi ini tidak akan berguna sama sekali. Rendahnya tingkat promosi ini dapat terlihat dari rata-rata (mean) untuk variabel promosi, yang hanya sebesar 2,87 . Ini artinya bahwa responden cenderung tidak setuju, keberadaaan promosi yang dilakukan oleh PT. XYZ.

Pengaruh positif dan signifikan antara variabel kepercayaan terhadap variabel keputusan pembelian juga berhasil ditemukan dan dibuktikan dalam penelitian ini. Penemuan ini sejalan dengan penelitian (Wakhidah, 2018), (Penia \& putu nina Madiawati, 2016) dan (Yuniarti, 2016). Hasiltemuan ini dapat diinteprestasikan bahwa meskipun ditengah pandemi Covid-19 yang sedang mewabah, masyarakat masih tetap mempercayai kualitas dan safety yang dilakukan oleh pihak PT. XYZ, sehingga masyarakat akan tetap membeli dan menikmati jasa yang disediakan oleh PT. XYZ dikemudian hari. Penurunan pembelian tiket PT. XYZhanyalah bersifat sementara, yaitu karena adanya larangan untuk bepergian, lockdown yang dilakukan oleh Pemerintah Indonesia dan Negara-negara lain di dunia. Namun ketika pandemi Covid-19 ini berlalu, maka masyarakat Indonesia pun akan tetap membeli tiket PT. XYZlagi.

Penelitian ini juga menemukan bahwa consumer review online, promosi dan kepercayaan secara bersama-sama berpengaruh positif dan signifikan terhadap keputusan pembelian. Kontribusi ketiga variabel ini terhadap variabel keputusan pembelian sebesar $44,6 \%$.

\section{Kesimpulan}

Hasil penelitian menunjukkan bahwa consumer review online masih tetap sangat berpengaruh terhadap keputusan pembelian ditengah pandemic Covid-19 sedang terjadi. Sementara promosi, meskipun juga berpengaruh terhadap keputusan pembelian, namun tingkat pengaruhnya sangat kecil. Adapun untuk kepercayaan, variabel ini juga berpengaruh terhadap keputusan pembelian.

Pada penelitian ini jumlah sampel yang digunakan cukup kecil, sehingga tidak bisa dilakukan multi kelompok analisis, seperti pembagian jenis kelamin, umur, wilayah dan lain-lain. Penelitian ini hanya terbatas pada PT. XYZ, sehingga tidak bisa untuk menghasilkan kesimpulan umum untuk negara Indonesia. Penelitian lebih lanjut bisa dengan menambahkan jumlah sampel, juga melibatkan sampel dibeberapa kota di Indonesia, sehingga hasil penelitian yang dicapai dapat digunakan untuk menghasilkan suatu kesimpulan yang umum untuk negara Indonesia.

\section{Referensi}

Aji, N. S., Djawahir, A. H., \& Rofiq, A. (2019). Promotions on Purchasing Decisions Mediated in Purchase Motivation. Journal of Applied Management, 17(1), 153-161.

Ayuningtiyas, K., \& Gunawan, H. (2018). Pengaruh Kepercayaan, Kemudahan Dan Kualitas Informasi. Journal of Applied Business Administration, 2(1), 152-165.

Batu, R. L., Monica, C., \& Aprilia, B. N. (2020). The Effect Of Promotion And Price On The Purchasing Decisions. Jurnal Manajemen Dan Bisnis, 4(1), 1-10.

Chang, A. Y. P. (2017). A study on the effects of Sales Promotion on consumer involvement and purchase intention in Tourism industry. Eurasia Journal of Mathematics, Science and Technology Education, 13(12), 8323-8330. https://doi.org/10.12973/ejmste/77903

Erlangga, H., Nani, Supiandi, G., Jasmani, \& Nuryani, A. (2020). The Effect Of Promotion On Purchase Decision at PT. Jaindo Metal 
Products in Bandung. HUMANIS (Humanities,Management and Science Proceedings), 1, 253-258.

Fong, S. W. L., Kian, T. P., Fern, Y. S., \& Quan, S. L. (2018). The impact of online consumer review to online hotel booking intention in Malaysia. International Journal of Supply Chain Management, 7(2), 140-145.

Kotler, P., \& Keller, K. L. (2020). Marketing Management (15th ed.). Pearson Pretice Hall.

Laili Hidayati, N. (2018). Pengaruh Viral Marketing, Online Consumer Riviews Dan Harga Terhadap Keputusan Pembelian Shopee Di Surabaya. Jurnal Pendidikan Tata Niaga (JPTN), 6(3), 77-84. https://jurnalmahasiswa.unesa.ac.id/index.php/ jptn/article/view/24741

Latief, F., \& Ayustira, N. (2020). Pengaruh Online Costumer Review Dan Customer Rating Terhadap Keputusan Pembelian Produk Kosmetik Di Sociolla. Jurnal Mirai Managemnt, 4(2), 122-136. https://journal.stieamkop.ac.id/index.php/mirai

Lupiyoadi, R. (2015). Manajemen Pemasaran Jasa Berbasis Kompetensi (3rd ed.). Salemba Empat.

Mo, Z., Li, Y.-F., \& Fan, P. (2015). Effect of Online Reviews on Consumer Purchase Behavior. Journal of Service Science and Management, 08(03), 419-424. https://doi.org/10.4236/jssm.2015.83043

Park, C. H., Park, Y. H., \& Schweidel, D. A. (2018). The effects of mobile promotions on customer purchase dynamics. International Journal of Research in Marketing, 35(3), 453-470. https://doi.org/10.1016/j.ijresmar.2018.05.001

Penia, A., \& putu nina Madiawati. (2016). The Efect Of Trust And Information Quality To Online Purchase Decision On The Site Www.Traveloka.Com Penia. E-Proceeding of Management :, 3(2), 1880-1887.

Tjiptono, F. (2018). Pemasaran Jasa - Prinsip, Penerapan, dan Penelitian. Andy Offset.

Wakhidah, E. N. (2018). Pengaruh Harga, Promotion Dan Customer Trust Terhadap Keputusan Pembelian Tiket Pesawat Secara Online Pada Situs Traveloka.com. Jurnal Manajemen Dirgantara, 11(2), 48-57.

Xie, K. L., Chen, C., \& Wu, S. (2015). Online Consumer Review Factors Affecting Offline Hotel Popularity: Evidence from Tripadvisor. Journal of Travel and Tourism Marketing, $33(2)$, 211-223. https://doi.org/10.1080/10548408.2015.10505 38

Yuniarti, Y. (2016). Pengaruh Kualitas Produk, Harga, dan Kepercayaan terhadap Keputusan Pembelian Produk Fashion Online. In Issn:0852-8349 (Vol. 18, Issue 1, pp. 27-37). 